\title{
The effects of topical treatment with 5-fluorouracil on potentially malignant lesions of mice oral mucosa
}

\author{
COSTA, G. B. F. *, ALMEIDA, E. R., CAVALCANTI, F. G. B. and \\ CASTRO, J. F. L.
}

\begin{abstract}
Department of Clinical and Preventive Dentistry, School of Dentistry, Universidade Federal de Pernambuco UFPE, Av. Prof. Moraes Rego, 1235, CEP 50670-901, Cidade Universitária, Recife, PE, Brazil

*E-mail: gillienecosta@hotmail.com
\end{abstract}

\begin{abstract}
Introduction: The 5-fluorouracil (5-FU) discloses a cure rate greater than 90 percent in potentially malignant lesions of skin. In the oral cavity, these lesions are treat in most cases with practice surgery, which reduces the number of patient involvement by malignant lesions, not being usual treatment with chemotherapeutic drugs. The aim of this study was to evaluate the effectiveness of the antineoplastic agent 5 -fluorouracil in orabase ${ }^{\circledR}$ in potentially malignant lesions of the lingual mucosa in mice. Materials and Methods: Swiss albino mice (Mus musculus) were submitted to carcinogen 4-nitroquinoline-1-oxide (4NQO), $100 \mu \mathrm{g} / \mathrm{ml}$ in drinking water for 8 weeks, and on developing potentially malignant lesions on the tongue, were treated daily, with topical 5 -FU in orabase ${ }^{\circledR}$ at concentrations of $0.5 \%$ and $5 \%$, for 3 weeks. The tongues were processed for analysis by light microscopy. Results: Treatment with 5 -FU in orabase ${ }^{\circledR}$ was shown to be effective in the histological degree of involution of the epithelial lesions of the tongue in the treated animals $(\mathrm{p}<0.05)$. However, when compared, there was no statistically significant difference between the two concentrations $(\mathrm{p}>0.05)$. Conclusions: The 5 -FU in orabase ${ }^{\circledR}$ was shown to be a feasible therapy in potentially malignant lesions of the oral cavity.
\end{abstract}

Keywords: 4-Nitroquinoline-1-Oxide, precancerous conditions, mice, fluorouracil.

\section{Introduction}

When the tissues of the oral cavity suffer the onset of a process of carcinogenesis, they begin to develop a grading of histological alterations, represented by potentially malignant lesions, which may develop into malignant lesions of the oral cavity, such as squamous cell carcinoma (ADISA, 2009; SCHOOP, NOTEBORN and JONG, 2009; CERERO-LAPIEDRA, BALADÉ-MARTÍNEZ, MORENO-LÓPEZ et al., 2010; MISHRA, 2012).

At present, the preventive model of health in Dentistry draws patients' attention to the occurrence of potentially malignant lesions in the oral cavity. They are instructed to avoid risk factors, perform self-examination and make periodic visits to the dentist. The goal of this strategy is to make it feasible to perform early diagnosis of cancer of the mouth, making a better prognosis possible by means of prompt and effective therapeutic intervention (NEVILLE and DAY, 2002).

Because of the importance of potentially malignant lesions in oral carcinogenesis (VÁZQUEZ-ÁLVAREZ, FERNÁNDEZGONZÁLEZ, GÁNDARA-VILA et al., 2010), various researchers have used experimental model with the purpose of promoting understanding of the multifactorial process of carcinogenesis, and develop strategies for the early treatment of initial lesions (RIBEIRO and SALVADORI, 2007). A feasible form of treatment would be therapeutic solutions that would act directly on the gene of cells, since there is a damage to the DNA (SCHOOP, NOTEBORN and JONG, 2009).

The agent, 5-fluorouracil (5-FU), a pyrimidine uracil analog, inhibits the synthesis of the precursors of DNA necessary for the replication of cells with the potential of malignancy, and has been used for approximately 50 years in oncological clinics (SAIF, CHOMA, SALAMONE et al., 2009) for the treatment of the most diverse types of cancer (TONG, XIE, HE et al., 2011).

In addition, 5-FU is also used topically in patients with dermatological alterations with potential risk of malignancy, with the resolution of 90 per cent of the cases (WERSCHLER, 2008), and in lesions present in the vaginal mucosa (DUONG and FLOWERS, 2007).

The development of a topical treatment for potentially malignant lesions in the oral cavity would favor patients with extensive lesions, since they would be saved from undergoing invasive and painful surgical procedures, as is still recommended (ADISA, 2009; RIBEIRO, SALLES, SILVA et al., 2010).

Starting from this principle, the aim of this study was to experimentally evaluate the effectiveness of topical treatment with the antineoplastic agent 5 -fluorouracil in potentially malignant lesions of the lingual mucosa of mice submitted to the carcinogen 4-nitroquinoline-1-oxide (4NQO).

\section{Materials and Methods}

\subsection{Animals}

Thirty-two Swiss Albino mice (Mus musculus), males, with age between 6 and 8 weeks old, and weighing between 20 and 23 grams, obtained from the vivarium of the Department of Antibiotics of the Federal University of Pernambuco (UFPE), formed part of the of the experiment. This study was approved by the Ethics Committee on the Use of 
Animals, of the Federal University of Pernambuco (Protocol $\mathrm{N}^{\circ}$ 23076.020913/2011-25).

The animals were weighed and divided into five experimental groups: Group A ( $n=6$, Control Group 1); Group B ( $n=7$, Control Group 2); Group C (n=6, 5-FU 0.5\%), Group D ( $\mathrm{n}=6$, 5 -FU 5\%) and Group E (n=7, orabase ${ }^{\circledR}$, Control Group 3). The maximum of 5 animals were kept in plastic cages lined with shavings, at a temperature of $22^{\circ} \mathrm{C}$, dark/light cycle of $12 \mathrm{~h} / 12 \mathrm{~h}$ and fed with rations ad libitum.

\subsection{Experimentation protocol}

Treatment with the carcinogen 4NQO (Sigma, St. Louis, MO, USA) followed the protocol described by Faria, Chammas, Melo et al. (2011). This protocol consist in dilute the 4NQO in filtered water until it attained the concentration of $100 \mu \mathrm{g} /$ $\mathrm{ml}$. The solutions were prepared and changed on a weekly basis before being used in the experiment, and placed in bottled wrapped in aluminum foil, in order to protect them from the action of ambient light.

All the animals were submitted to the carcinogen 4NQO in the drinking water, ad libitum, at the concentration of $100 \mu \mathrm{g} / \mathrm{ml}$ for 8 weeks, and kept on filtered water and rations ad libitum for another 8 weeks, as established in the study of Hasina, Martin, Kasza et al. (2009). This protocol that use the carcinogen in the drinking water is the best to induce oral carcinogenesis, when compared with the induction by others forms (HASINA, MARTIN, KASZA et al., 2009).

Each experimental group was submitted to different experimental protocols after the period of time of carcinogenesis. The group A (Control Group 1) was anesthetized and sacrificed, in order to establish the degree of histological alteration in which the treatment of the groups C, D and E was started. After this same time interval (16 weeks), the group B (Control Group 2) remained in the experiment for another 3 weeks receiving filtered water and rations ad libitum, in order to compare the histological degree of lesions with the treated groups. The groups C, D and E (Control Group 3) had their tongues treated for 3 weeks with a single daily topical application of 5 -FU $0.5 \%, 5$-FU $5 \%$ and orabase ${ }^{\circledR}$, respectively. After this time, they were anesthetize and sacrificed (Table 1). The animals were sacrificed with an overdose of anesthetic and the total time of the experimental stage consisted of 19 weeks.

The 5-FU was applied topically and daily on the dorsum of the tongue of animals with the aid of a paintbrush. The animals were restrained manually, without anesthesia, and their tongues were tensioned using a forceps. After application, the animal remained completely restricted from drinking water for 3 hours, in order to enable the longest time of contact of the 5 -FU in orabase ${ }^{\circledR}$ with the lingual mucosa. Orabase ${ }^{\circledR}$ is a protective paste wich adheres to mucous membranes and moist skin surfaces.

\subsection{Macroscopic exam of the lingual mucosa}

After sacrificed by anesthetic overdose, the tongues of the mice were removed and analyzed immediately for the presence of clinically visible lesions. The location of these lesions was recorded, in order to make it possible to associate them with the histopathological diagnosis. The tongues were fixed in buffered formalin solution (10\%, $\mathrm{pH} 7.4)$ for 24 hours. The specimens were sent to the Oral Pathology Laboratory where the macroscopic exam and cross sectioning into six fragments was performed, (two from each third: apex, middle portion and base of the tongue), for individual evaluation of each third.

\subsection{Histopathological exam of specimens}

The fragments were dehydrated in ascending grades of ethyl alcohol solutions, and diaphanized in xylol for embedment in paraffin. Histological sections of $5 \mu \mathrm{m}$ thickness were obtained, which were stained with hematoxylin and eosin (HE) for microscopic analysis.

These fragments were analyzed under a light microscope Olympus BX 41 at 40X, 100X and 400X magnifications, by an experienced pathologist, blind to the experiment. The highest degree of histological involvement was considered in the cases in which there were different degrees in the same histological section. Diagnosis was made in accordance with the histological grading systems proposed by the World Health Organization - WHO (BARNES, EVENSON, REICHART et al., 2005), with the following alterations being evaluated and recorded: irregular epithelial stratification; loss of polarity of the basal layer cells; epithelial projections in drop form; increase in the number of mitotic figures; keratin pearls in epithelial projections; nucleus of an abnormal size and shape, with hyperchromatism; abnormal variation in cell size; cellular pleomorphism; increase in nucleus/cytoplasm proportion. In order to make statistical analysis possible, the lesions were quantified in numerical values in an ascending order, according to the severity of the lesion (Table 2 ).

\section{Statistical Analysis}

To compare the thirds of the tongue and establish which of them obtained the highest degree of histological involvement, the Friedman test was used. The Mann Whitney test was adopted to compare the experimental groups with one another, to evaluate whether the treatment with 5-FU was effective, and which concentration was most efficient,

Table 1. Experimental protocol used in each group of animals.

\begin{tabular}{cccccccc}
\hline Groups & $\begin{array}{c}\mathbf{N}^{\circ} \text { of mice } \\
\text { at week 0 }\end{array}$ & $\begin{array}{c}\mathbf{N}^{\circ} \text { of mice } \\
\text { surviving at } \\
\text { end }\end{array}$ & 4NQO* & $\begin{array}{c}\text { Weeks of } \\
\text { monitoring }\end{array}$ & $\begin{array}{c}\text { Method } \\
\text { after 4NQO }\end{array}$ & $\begin{array}{c}\text { Time of } \\
\text { treatment* }\end{array}$ & $\begin{array}{c}\text { Total } \\
\text { weeks of } \\
\text { experiment }\end{array}$ \\
\hline A & 6 & 5 & 8 & 8 & X & X & 16 \\
B & 7 & 5 & 8 & 11 & X & X & 19 \\
C & 6 & 5 & 8 & 8 & $5-F U ~ 0.5 \%$ & 3 & 19 \\
D & 6 & 5 & 8 & 8 & $5-F U ~ 5 \%$ & 3 & 19 \\
E & 7 & 5 & 8 & 8 & Orabase & 3 & 19 \\
\hline
\end{tabular}

*Weeks. 
and also to establish the relationship between the absence of visible lesion and histological involvement. The software program SPSS (Statistical Package for the Social Sciences) version 13 (SPSS Inc., Chicago, USA), was used. The level of significance of $5 \%(\mathrm{p}<0.05)$ was determined.

\section{Results}

This experiment began with a total of 32 mice. However, 7 of the animals died during the period of 4 NQO administration. This resulted in a loss of $28 \%$ of the initial sample, resulting in a final sample of 25 animals, distributed into 5 groups of 5 mice.

\subsection{Histopathological analysis}

All the tongues examined (100\%) revealed some histological involvement, which varied among hyperplasia and/or

Table 2. Histological characteristics of the oral epithelium, which made it possible to reach the histopathological diagnosis ( BARNES, EVENSON, REICHART et al., 2005).

\begin{tabular}{|c|c|c|}
\hline Score & Diagnosis & Histological Characteristic \\
\hline 1.0 & Normal & ------- \\
\hline 2.0 & Hyperplasia and/or hyperkeratosis & $\begin{array}{l}\text { Acanthosis of the prickle cell layer and increase in the } \\
\text { keratotic layer }\end{array}$ \\
\hline 3.0 & Slight Dysplasia & $\begin{array}{l}\text { Alterations are restricted to the inferior third of the } \\
\text { epithelium (basal and parabasal layers) }\end{array}$ \\
\hline 3.4 & Moderate dysplasia & $\begin{array}{l}\text { Alterations attain the middle third of the epithelium } \\
\text { (middle portion of the spiny layer }\end{array}$ \\
\hline 3.8 & Severe dysplasia & Alterations exceed the middle third of the epithelium \\
\hline 4.0 & Invasive Carcinoma & $\begin{array}{l}\text { Isles of cancerigenous cells in the depth of the } \\
\text { conjunctive tissue }\end{array}$ \\
\hline
\end{tabular}
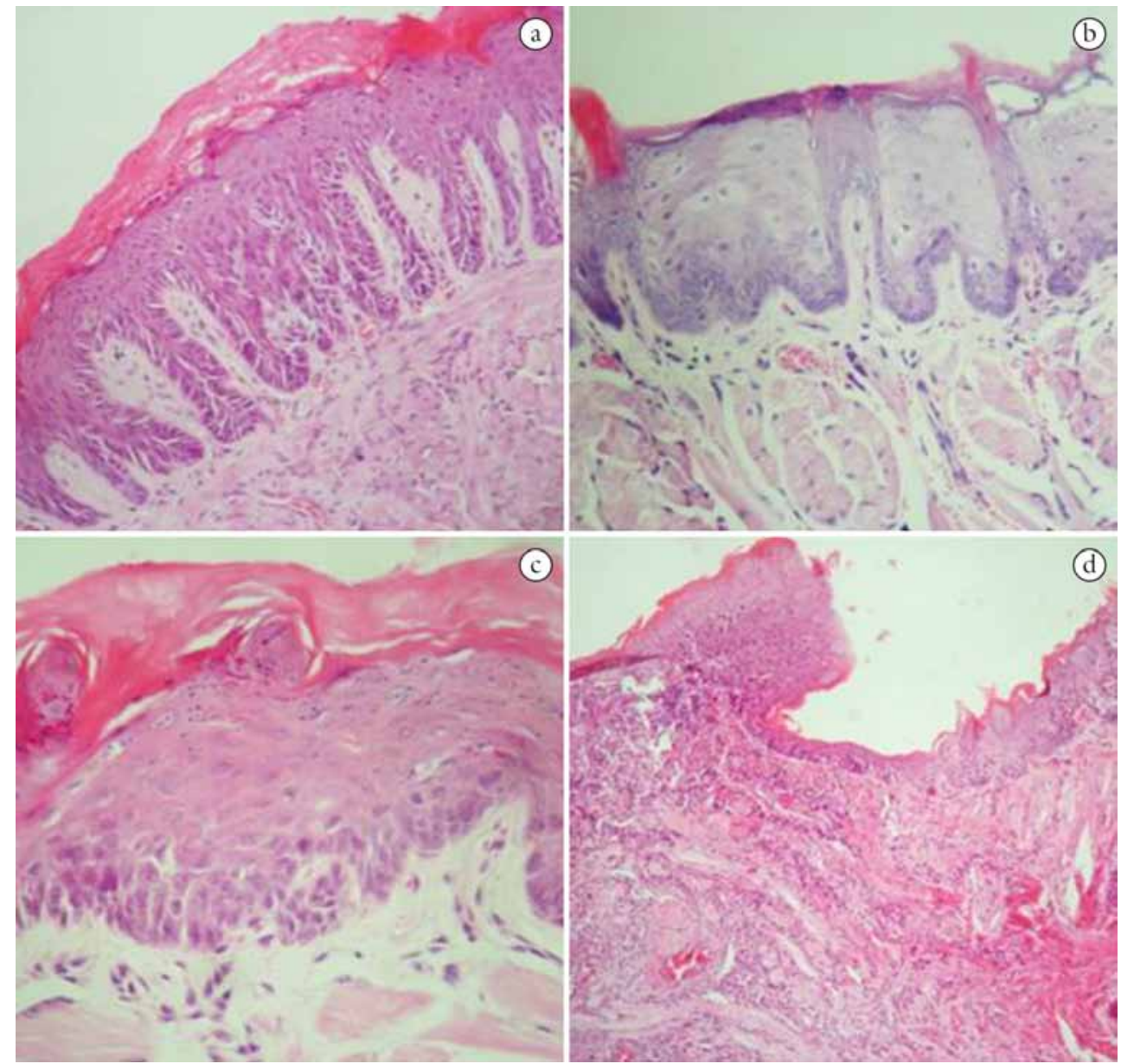

Figure 1. Histopathological evidence of carcinogenesis in the tongues of the mice. Mice submitted to $4 \mathrm{NQO}, 100 \mu \mathrm{g} / \mathrm{ml}$, in drinking water. (a) Moderate dysplasia in a mice tongue in Group C, treated with 5 -FU in orabase ${ }^{\circledR}$ at $0.5 \%(\mathrm{H} / \mathrm{E}-200 \mathrm{x})$. (b) Slight dysplasia in a mice tongue in Control Group 3, treated with orabase ${ }^{\circledR}$ only $(\mathrm{H} / \mathrm{E}-200 \mathrm{x})$. (c) Slight dysplasia in a mice tongue in Control Group 2, treated with 4NQO only $(\mathrm{H} / \mathrm{E}-200 \mathrm{x})$. (d) Invasive carcinoma in animal of Group A, Control $1(\mathrm{H} / \mathrm{E}-200 \mathrm{x})$. 
hyperkeratosis, discrete dysplasia, moderate dysplasia, severe dysplasia and invasive carcinoma (Figure 1).

The groups treated with 5 -FU in orabase ${ }^{\circledR}$ (Groups C and D) were those which presented the lowest degree of histopathological alteration, with remarkable presence of hyperplasia with hyperkeratosis (Table 3 ).

When compared with Control Group 2 (Group B), the groups treated with 5 -FU in orabase ${ }^{\circledR}$ showed statisically significant values as regards the involution in the degree of potentially malignant lesions $(\mathrm{p}<0.05)$. However, when compared with one another, there was no statistically significant difference $(p>0.05 \%)$ in the effectiveness of the treatment among them; that is to say, any of the concentrations were efficient for the treatment of potentially malignant lesions of the lingual mucosa of mice.

The treatment with 5-FU began in the stage of the greatest prevalence of potentially malignant lesions of the light dysplasia type, as shown in Group A (Control Group 1). Nevertheless, after 3 more weeks of follow-up of Group B (Control Group 2) had passed, there was development in the degree of the lesions, with moderate dysplasia prevailing, without statistically significant differences among the groups $(\mathrm{p}>0.05)$ (Table 3$)$.

Table 3. Histopathological aspects of the highest degree observed in the different groups studied.

\begin{tabular}{|c|c|c|c|c|c|c|c|c|c|c|c|c|c|c|c|c|c|c|c|c|c|c|c|c|c|}
\hline \multirow{3}{*}{ Histopathological } & \multicolumn{25}{|c|}{ Groups } \\
\hline & \multicolumn{5}{|c|}{ A } & \multicolumn{5}{|c|}{ B } & \multicolumn{5}{|c|}{$\mathrm{C}$} & \multicolumn{5}{|c|}{$\mathrm{D}$} & \multicolumn{5}{|c|}{$\mathrm{E}$} \\
\hline & 1 & 2 & 3 & 4 & 5 & 1 & 2 & 3 & 4 & 5 & 1 & 2 & 3 & 4 & 5 & 1 & 2 & 3 & 4 & 5 & 1 & 2 & 3 & 4 & 5 \\
\hline Normal & & & & & & & & & & & & & & & & & & & & & & & & & \\
\hline Hyperplasia and/or hyperkeratosis & & & & & & & & & & & $\mathrm{x}$ & $\mathrm{x}$ & $\mathrm{x}$ & & & $\mathrm{x}$ & & $\mathrm{x}$ & $\mathrm{x}$ & $\mathrm{x}$ & & & & & \\
\hline Slight Dysplasia & $\mathrm{x}$ & & $\mathrm{x}$ & $\mathrm{x}$ & $\mathrm{x}$ & $\mathrm{x}$ & & & & & & & & & $\mathrm{x}$ & & & & & & $\mathrm{x}$ & & & & \\
\hline Moderate Dysplasia & & & & & & & $\mathrm{x}$ & $\mathrm{x}$ & $\mathrm{x}$ & $\mathrm{x}$ & & & & $\mathrm{x}$ & & & $\mathrm{x}$ & & & & & & $\mathrm{x}$ & $\mathrm{x}$ & \\
\hline Severe Dysplasia & & & & & & & & & & & & & & & & & & & & & & $\mathrm{x}$ & & & \\
\hline Invasive Carcinoma & & $\mathrm{x}$ & & & & & & & & & & & & & & & & & & & & & & & $\mathrm{x}$ \\
\hline
\end{tabular}

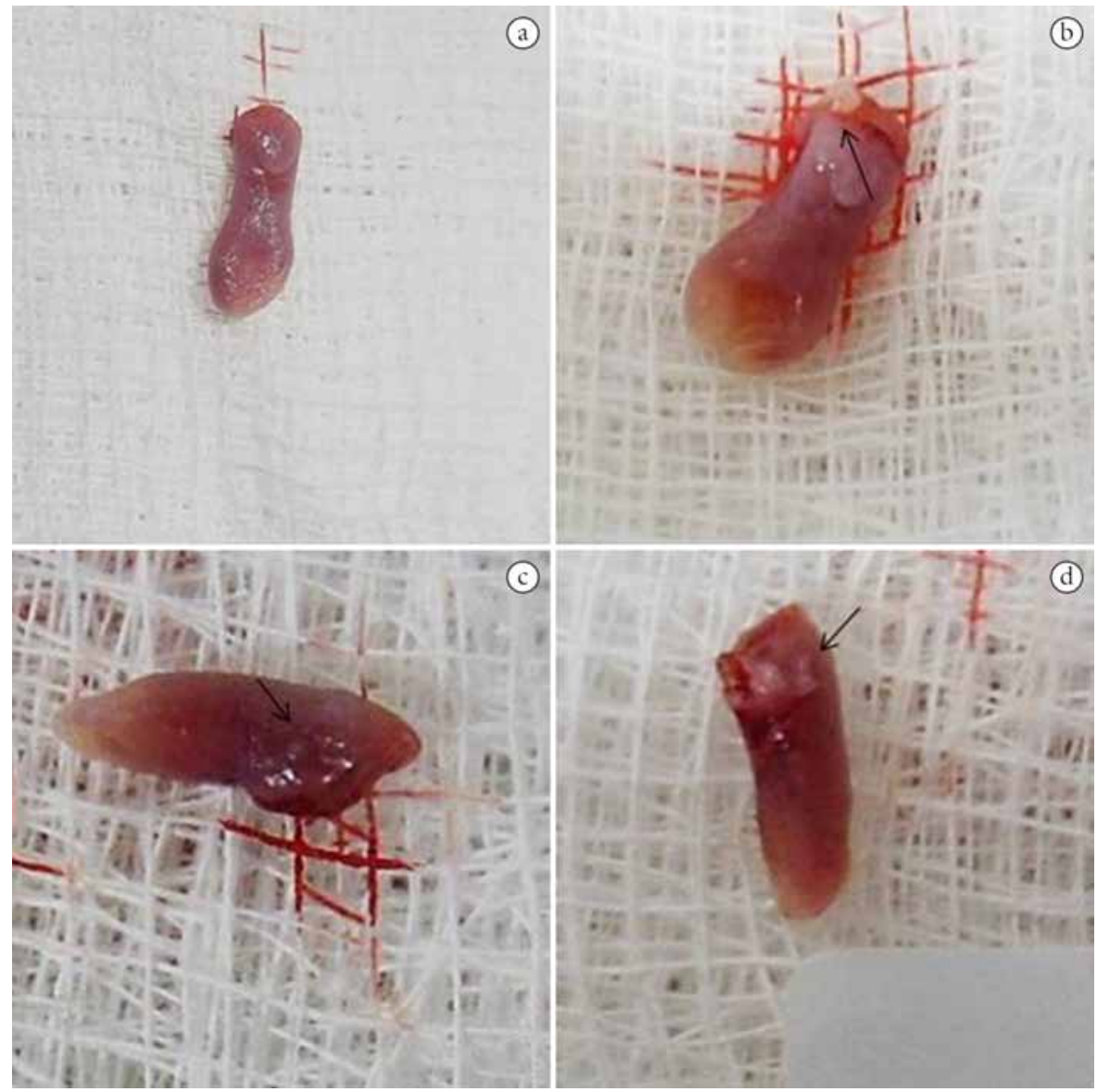

Figure 2. Macroscopic analysis of the studied mice tongues. Observation made immediately after the sacrificed of the animals. (a) Tongue with an aspect of normality in Group A, and histopathological diagnosis of invasive carcinoma. (b) Whitened papular lesion in the posterior third of the tongue of an animal from Group D, with histopathological diagnosis of hyperplasia and hyperkeratosis. (c) Small papular lesion on the lateral border and posterior region of the tongue of mice from Group E, with histopathological diagnosis of discrete dysplasia. (d) Tongue of a mice from Group D, with whitened papular lesions in the posterior region, and histopathological diagnosis of hyperplasia and hyperkeratosis. 


\subsection{Macroscopic analysis of the tongues}

Macroscopic analysis of the tongues revealed the absence of visible lesions in Group A in 16 weeks of the experiment, and the occurrence of papular lesions in the animals in Groups B, C, D and E, 19 weeks after the experiment began (Figure 2).

When the correlation between the absence of macroscopically visible lesion and the microscopic aspect of the specimen were evaluated, it was observed that even in the absence of visible lesions there was involvement in the microscopic aspect $(\mathrm{p}=0.244)$, since histological alteration occurred in $100 \%$ of the tongues, and the presence of clinically visible lesions in only $36 \%$ of them.

\subsection{Histopathological analysis of the thirds of the tongue}

In macroscopy, the tongues of the animals were divided into thirds (apex, middle portion and base), in order to make more detailing possible in the microscopy analysis.

The base of the tongue was affected by a greater histological degree of alteration, when compared with the other thirds, showing statistical significance $(\mathrm{p}>0.05)$.

The record of the location of the clinically visible lesion made it possible to associate it with its histopathological diagnosis, revealing that the base of the tongue, in addition to having presented the highest histological degree of involvement, also presented the majority of the clinically visible lesions $(77.7 \%)$, with the remainder $(22.3 \%)$ occurring in the middle portion.

\section{Discussion}

By means of the topical treatment with 5 -Fluorouracil in orabase ${ }^{\circledR}$ at the concentrations of $0.5 \%$ and $5 \%$ on the mucosa of the dorsum of the tongue of mice in this study, it was possible to observe the involution of potentially malignant lesions when treated at the initial stage of dysplasia. This early intervention with 5-FU cream has already been well established in potentially malignant skin lesions, with a percentage of cure of over 90 per cent (WERSCHLER, 2008).

This form of therapy against potentially malignant lesions of the oral mucosa, has been revealed, from the preventive point of view, as very effective, since the histopathological diagnosis of these lesions may represent a risk for predisposition to cancer of the mouth (JABER, 2010). In spite of the fact that the minority of these epithelial alterations transform into malignant lesions, should they be diagnosed and treated at an early stage, the make it possible for the patient to have a better prognosis with greater chances of cure ( ISLAM, KORNBERG, VEENKER et al., 2010).

The results of this study were obtained in the lingual mucosa of mice, because this is one of the sites most affected by dysplastic lesions in humans (VÁZQUEZ-ÁLVAREZ, FERNÁNDEZGONZÁLEZ, GÁNDARA-VILA et al., 2010), and because the organisms of mice represent more faithfully what occurs in a human organism. This study showed new results, differently from the articles present in the literature, in which the results of the topical action of 5-FU were obtained in experimental models with the use of reconstituted human oral epithelium (in vitro) and in pig oral mucosa (ex vivo) (GIANNOLA, DE CARO, GIANDALIA et al., 2010).

This involution in the histological degree of the lesions was confirmed by the prevalence of slight dysplastic lesions of the epithelium in the control group at the beginning of treatment; and after the elapse of 3 weeks of daily topical application of 5 -FU in orabase ${ }^{\circledR}$, by the remarkable presence of lesions with the lower histological degree, such as hyperplasias. These are data that corroborate the studies of other authors, who have affirmed that after the first week of treatment with a single daily application of 5-FU, there already was a reduction in the histological degree of the lesions, and this time could be a maximum of 4 weeks (WERSCHLER, 2008; TUTRONE, SAINI, CAGLAR et al., 2003).

By the state of debility the animals began to present at the end of 3 weeks of a daily single topical application of 5-FU in orabase $^{\circledR}$, the maximum time of 4 weeks was not attained, and the treatment was discontinued, as occurs with patients who make use of this antineoplastic agent applied topically to the skin. Because of the side effects, such as tissue irritability, there is discontinuity in its use and the prognosis is compromised (WERSCHLER, 2008).

As there was no difference with regard to the effectiveness of the different concentrations of 5-FU in orabase ${ }^{\circledR}$ against the potentially malignant lesions of the lingual mucosa, the administration of the lower concentration, according to the literature, would biologically be more acceptable, because it would cause fewer side effects, and enable a longer time of treatment (WERSCHLER, 2008).

In order to be able to obtain these results, it was initially necessary to induce potentially malignant lesions in the lingual mucosa of the animals, which were afterwards treated with 5 -FU in orabase ${ }^{\circledast}$. The 4-nitroquinoline-1-oxide (4NQO) was the carcinogen selected and used because it enabled the induction of all the stages of carcinogenesis ( HASINA, MARTIN, KASZA et al., 2009) by means of the process of mutation, since the genetic information was adulterated and fixed ( TANG, KNUDSEN, BEMIS et al., 2004). This property was observed in the carcinogenesis induction model used in this study, in which it was possible to observe the formation of the most varied histological alterations in the epithelial tissue of the tongues of the animals, such as: hyperplasia, light, moderate and severe epithelial dysplasia, and invasive carcinoma.

The predictability in obtaining these epithelial alterations occurred by means of the administration of $4 \mathrm{NQO}$ in the animals' drinking water (JIANG, YE, QIU et al., 2007). This is a protocol that enable the formation of the histological lesions in the oral cavity of all the animals and that is adopt as the gold standard for the induction of oral carcinogenesis (FRACALOSSI, SILVA, OSHIMA et al., 2010; HIRSHBEG, DAYAN, VERED et al., 2003), in spite of the long time required for the formation of the lesions and the relative mortality rate of the animals (JIANG, YE, QIU et al., 2007). In this experiment occurred the loss of $28 \%$ of the initial sample during the period of administration of the carcinogen.

With the passage of time after the administration of 4NQO, there was a tendency towards an increase in the histological degree of severity of the lesions, going from a higher percentage of light dysplasia to a higher degree of moderate dysplasia, as the time of observation of the animals went by. Other authors who used this experimental protocol also observed this occurrence (VÁZQUEZ-ÁLVAREZ, FERNÁNDEZ-GONZÁLEZ, GÁNDARA-VILA et al., 2009).

In general, with regard to the involvement by lesions observed histologically in the thirds of the tongue, the region of the base of the tongue was that which presented the greatest 
severity in the degree of the lesions, probably because it is the site of greatest contact with the carcinogen while it is being swallowed (VERED, ALLON and DAYAN, 2009).

It is worth emphasizing that in spite of all the animals having presented some histological alteration in the epithelium of the tongue, not all the microscopically confirmed lesions were clinically visible, as observed in a previous report (WILKEY, BUCHBERGER, SAUCIER et al., 2009).

\section{Conclusion}

The antineoplastic agent 5 -fluorouracil in orabase ${ }^{\circledR}$ was effective in the involution of the degree of potentially malignant lesions in the mucosa of the dorsum of the tongue of the mice, when topically applied daily for 3 weeks, and there was no statistically significant difference between the concentrations of $0.5 \%$ and $5 \%$.

Acknowledgements: The Authors thank CAPES - "Coordenação de Aperfeiçoamento de Pessoal de Nível Superior - CAPES”, (Personal Improvement Coordination for Higher Education) for the financial support to conduct this study.

\section{Conflict of interest}

The authors declare that they have no conflict of interest.

\section{References}

ADISA, AO. Oral squamous cell carcinoma. Dentoscope, 2009, vol. 16, p. 1-4.

BARNES, L., EVENSON, JW., REICHART, P. and SIDRANSKY, D. (Eds.). World Health Organization Classification of Tumours. Pathology and genetics of head and neck tumours. Lyon: International Agency for Research on Cancer Press, 2005. p. 163-208.

CERERO-LAPIEDRA, R., BALADÉ-MARTÍNEZ, D., MORENOLÓPEZ, L., ESPARZA-GÓMEZ, G. and BAGÁN, JV. Proliferative verrucous leukoplakia: a proposal for diagnostic criteria. Medicina Oral, Patologia Oral y Cirugia Bucal, 2010, vol. 15, n. 6, p. e839-e845. http://dx.doi.org/10.4317/medoral.15.e839. PMid:20173704.

DUONG, TH. and FLOWERS, LC. Vulvo-vaginal cancers: risks, evaluation, prevention and early detection. Obstetrics and Gynecology Clinics of North America, 2007, vol. 34, n. 4, p. 783-802 http:// dx.doi.org/10.1016/j.ogc.2007.10.003. PMid:18061869.

FARIA, PR., CHAMMAS, R., MELO, TL., HSU, DK., LIU, FT., NONOGAKI, S., CARDOSO, SV. and LOYOLA, AM. Absence of galectin-3 does not affect the development of experimental tongue carcinomas in mice. Experimental and Molecular Pathology, 2011, vol. 90, n. 2, p. 189-193. http://dx.doi.org/10.1016/j. yexmp.2010.12.007. PMid:21194530.

FRACALOSSI, AC., SILVA, MS., OSHIMA, CT. and RIBEIRO, DA. Wnt/ $\beta$-catenin signalling pathway following rat tongue carcinogenesis induced by 4-nitroquinoline 1-oxide. Experimental and Molecular Pathology, 2010, vol. 88, n. 1, p. 176-183. http://dx.doi. org/10.1016/j.yexmp.2009.11.004. PMid:19931241.

GIANNOLA, LI., DE CARO, V., GIANDALIA, G., SIRAGUSA, MG., PADERNI, C., CAMPISI, G. and FLORENA, AM. 5-Fluorouracil buccal tablets for locoregional chemotherapy of oral squamous cell carcinoma: formulation, drug release and histological effects on reconstituted human oral epithelium and porcine buccal mucosa. Current Drug Delivery, 2010, vol. 7, n. 2, p. 109-117. http://dx.doi. org/10.2174/156720110791011792. PMid:20158481.
HASINA, R., MARTIN, LE., KASZA, K., JONES, CL., JALIL, A. and LINGEN, MW. ABT-510 Is an effective chemopreventive agent in the mouse 4-nitroquinoline 1-oxide model of oral carcinogenesis. Cancer Prevention Research, 2009, vol. 2, n. 4, p. 385-393. http:// dx.doi.org/10.1158/1940-6207.CAPR-08-0211. PMid:19336725.

HIRSHBEG, A., DAYAN, D., VERED, M., YAACOB, Y., AMARIGLIO, N., RECHAVI, G. and KAPLAN, I. Experimental oral carcinogenesis in rats: histomorphometric study and global gene expression. Oral Surgery, Oral Medicine, Oral Pathology. Oral Radiology and Endodontology, 2003, vol. 96, n. 3, p. 303.

ISLAM, MN., KORNBERG, L., VEENKER, E., COHEN, DM. and BHATTACHARYYA, I. Anatomic site based ploidy analysis of oral premalignant lesions. Head and Neck Pathology, 2010, vol. 4, n. 1, p. 10-14. http://dx.doi.org/10.1007/s12105-009-0151-0. PMid:20237983.

JABER, MA. Oral epithelial dysplasia in non-users of tobacco and alcohol: an analysis of clinicopathologic characteristics and treatment outcome. Journal of Oral Science, 2010, vol. 52, n. 1, p. 13-21. http:// dx.doi.org/10.2334/josnusd.52.13. PMid:20339228.

JIANG, C., YE, D., QIU, W., ZHANG, X., ZHANG, Z., HE, D., ZHANG, P. and CHEN, W. Response of lymphocyte subsets and cytokines to Shenyang prescription in Sprague-Dawley rats with tongue squamous cell carcinomas induced by 4 NQO. BMC Cancer, 2007, vol. 7, n. 1, p. 1-9. http://dx.doi.org/10.1186/1471-24077-40. PMid:17338814.

MISHRA, R. Biomarkers of oral premalignant epithelial lesions for clinical application. Oral Oncology, 2012, vol. 48, n. 7, p. 578-584. http:// dx.doi.org/10.1016/j.oraloncology.2012.01.017. PMid:22342569.

NEVILLE, BW. and DAY, TA. Oral cancer and precancerous lesions. A Cancer Journal for Clinicians, 2002, vol. 52, p. 195-215.

RIBEIRO, AS., SALLES, PR., SILVA, TA. and MESQUITA, RA. A review of the nonsurgical treatment of oral leukoplakia. International Journal of Dentistry, 2010, vol. 2010, p. 1-10. http://dx.doi. org/10.1155/2010/186018. PMid:20339486.

RIBEIRO, DA. and SALVADORI, DMF. Gingival changes in wistar rats after oral treatment with 4 -Nitroquinoline 1-oxide. European Journal of Dentistry, 2007, vol. 1, p. 152-157.

SAIF, MW., CHOMA, A., SALAMONE, SJ. and CHU, E. Pharamacokinetically guided dose adjustment of 5-fluorouracil: a rational approach to improving therapeutic outcomes. Journal of the National Cancer Institute, 2009, vol. 101, n. 22, p. 1543-1552. http://dx.doi.org/10.1093/jnci/djp328. PMid:19841331.

SCHOOP, RA., NOTEBORN, MH. and JONG, RJB. A mouse model for oral squamous cell carcinoma. Journal of Molecular Histology, 2009, vol. 40, n. 3, p. 177-181. http://dx.doi.org/10.1007/s10735-0099228-z. PMid:19685146.

TANG, XH., KNUDSEN, B., BEMIS, D., TICKOO, S. and GUDAS, LJ. Oral cavity and esophageal carcinogenesis modeled in carcinogentreated mice. Clinical Cancer Research, 2004, vol. 10, n. 1, Pt 1, p. 301-313. http://dx.doi.org/10.1158/1078-0432.CCR-0999-3. PMid:14734483.

TONG, J., XIE, G., HE, J., LI, J., PAN, F. and LIANG, H. Synergistic antitumor effect of dichloroacetate in combination with 5 -fluorouracil in colorectal cancer. Journal of Biomedicine \& Biotechnology, 2011, vol. 2011, p. 740564. http://dx.doi.org/10.1155/2011/740564. PMid:21403907.

TUTRONE, WD., SAINI, R., CAGLAR, S., WEINBERG, JM. and CRESPO, J. Topical therapy for actinic keratoses, i: 5-fluorouracil and imiquimod. Cutaneous Medicine for the Practitioner, 2003, vol. 71, n. 5, p. 365-370. PMid:12769403.

VÁZQUEZ-ÁLVAREZ, R., FERNÁNDEZ-GONZÁLEZ, F., GÁNDARA-VILA, P., REBOIRAS-LÓPES, D., GARCÍA-GARCÍA, A. and GÁNDARA-REY, J. Correlation between clinical and pathologic 
COSTA, G. B. F., ALMEIDA, E. R., CAVALCANTI, F. G. B. et al.

diagnosis in oral leukoplakia in 54 patients. Medicina Oral Patología Oral y Cirugía Bucal, 2010, vol. 15, p. 832-838.

VERED, M., ALLON, I. and DAYAN, D. Maspin, p53, p63, and Ki-67 in epithelial lesions of the tongue: from hyperplasia through dysplasia to carcinoma. Journal of Oral Pathology \& Medicine, 2009, vol. 38, n. 3, p. 314-320. http://dx.doi.org/10.1111/j.16000714.2008.00698.x. PMid:18783348.

WERSCHLER, WP. Considerations for use of fluorouracil cream $0.5 \%$ for the treatment of actinic keratosis in elderly patients. The Journal of Clinical and Aesthetic Dermatology, 2008, vol. 1, n. 2, p. 22-27. PMid:21103319.
WILKEY, JF., BUCHBERGER, G., SAUCIER, K., PATEL, SM., EISENBERG, E., NAKAGAWA, H., MICHAVLIRA, CZ., RUSTIGY, AK. and MALLYA, SM. Cyclin Dl overexpression increases susceptibility to 4-nitroquinoline-1-oxide-induced dysplasia and neoplasia in murine squamous oral epithelium. Molecular Carcinogenesis, 2009, vol. 48, p. 853-861.

Received October 20, 2015

Accepted September 24, 2015 